За методом аналізу ієрархій (MAI) розроблено методичний підхід визначення пріоритетної технології фіторемедіації для очищення стічних вод від населених пунктів. Розроблений підхід дозволяє задіяти експертів муніципальних органів управління населеного пункту, де плануеться будівництво очисних споруд, до обгрунтування рішень в управлінні екологічною безпекою поверхневих водних об'єктів, розташованих біля зазначених населених пунктів.

Запропоновано критерії (групи факторів), що відображають: вхідні та вихідні параметри системи очищення; обставини, які складаються в місці побудови очисних споруд, та вимоги, які безпосередньо відносяться до технологій фіторемедіаиії. Експерти різної фахової спрямованості дають власні судження відносно пріоритетності переваг зазначених критеріальних ознак. Багатодисииллінарні судження експертів, які відображають специфічні особливості фіторемедіацї̈ та умови майбутнъого місия розташування очисних споруд, оброблені за науково обтрунтованою прочедурою МАI, є основою для прийняття рімень при виборі пріоритетної технологї фіторемедіачії в конкретних умовах.

До переваг методичного підходу, що запропонований, слід віднести можливість ув'язати до єдиного алгоритму обтрунтування рішення весь масив необхідної інформації. Ця інформація розрізняеться $я к$ за своїм змістом (екологічна, біологічна, містобудівна, соціальна та економічна), так $і$ за формою представлення (дані безпосередніх вимірів, статистичні та прогнозні очінки).

Апробачія запропонованого методичного підходу проводилась на прикладі вибору технологій фіторемедіації для очисних споруд трьох об'єктів різного виду: промислового підприємства, житлової забудови та міської лікарні. Отримані результати мали рівень узгодженості в межах допустимого, що свідчить про їх достовірність.

Розроблений методичний підхід призначений для прийняття управлінських рімень при виборі технології фіторемедіації на очисних спорудах при обгрунтуванні їх удосконалення чи побудові нових споруд

Ключові слова: екологічна безпека, фіторемедіація та ї̈ технологї, вищі водні рослини, об'єкти населеного пункту, метод аналізу ієрархій

Received date 03.02.2020

Accepted date 06.04.2020
UDC 504.4.054:614.777

DOI: $10.15587 / 1729-4061.2020 .200591$

\section{CHOOSING THE PHYTOREME- DIATION TECHNOLOGIES FOR CLEANING VARIOUS TYPES OF WASTEWATER}

\author{
O. D m itrieva \\ Doctor of Economic Sciences, Senior Researcher, \\ Deputy Director for Research and Marketing Research* \\ E-mail: dmitrieva.olena@gmail.com \\ I. K horenz ha ja \\ $\mathrm{PhD}$, Head Consultant
}

The Committee of the Verkhovna Rada of Ukraine on Environmental Policy and Utilization of Natural Resources Hrushevskoho str., 5, Kyiv, Ukraine, 01008 E-mail: khorenzhaja@v.rada.gov.ua

V. V a s y le n ko

$\mathrm{PhD}$, Associate Professor** E-mail: vp_vasilenko@ukr.net

S. O s y pe n k o

$\mathrm{PhD}$, Associate Professor**

E-mail: snos-43@ukr.net

N. Teli u r a

$\mathrm{PhD}$, Associate Professor Department***

E-mail: nata.teliura@ukr.net

0. Lomakina

Senior Lecture***

E-mail: oslomakina@ukr.net

L. Mel n i k

Researcher*

E-mail: melnik2017@meta.ua

I. Koldoba

Head of Department

Department of Ecologically Safe Nature Management of Human Settlements and Economic Facilities*

E-mail: ivkoldoba@ukr.net

*Scientific Research Institution «Ukrainian Scientific Research Institute of Ecological Problems» (USRIEP)

Bakylina str., 6, Kharkiv, Ukraine, 61166

**Department of Combat and Logistics Support National Academy of the National Guard of Ukraine Zakhysnykiv Ukrainy sq., 3, Kharkiv, Ukraine, 61001 ***Department of Environmental Engineering O. M. Beketov National University of Urban Economy in Kharkiv Marshala Bazhanova str., 17, Kharkiv, Ukraine, 61002

Copyright (C) 2020, O. Dmitrieva, I. Khorenzhaja, V. Vasylenko,

S. Osypenko, N. Teliura, O. Lomakina, L. Melnik, I. Koldoba This is an open access article under the CC BY license (http://creativecommons.org/licenses/by/4.0)

\section{Introduction}

The development of society is, among other things, a history of increasing water consumption by industry, housing, and agriculture. Water pollution is a global environmental problem of our time. Used water goes into ponds and rivers, and almost a third of it gets there without proper purification. 
The main reasons for the discharge of polluted wastewater are a lack of implementation of environmentally friendly water management in drainage systems and low efficiency of existing urban wastewater treatment plants based on traditional treatment technologies in most countries. This is especially true for plants for the treatment of wastewater from small settlements $(S)$ and single-site plants (businesses, hospitals, residential areas, military sites, etc.). This also applies to treatment plants of large cities, which operate under conditions of certain problems in their energy and economic spheres and do not always ensure project efficiency.

In fact, there is a need to refocus traditional treatment systems on easy-to-use and low-energy methods based on the application of natural self-purification processes.

Self-purification processes are leading processes, which take place in any water body. These processes maintain equilibrium in an aquatic system and eliminate toxic substances, which get into the aquatic environment in different ways. Self-purification occurs through natural chemical and biological processes that take place in the phytocenosis of higher aquatic plants (HAP) and with their participation. Plants not only consume substances dissolved in water, but they are also a substrate for the development of a variety of microflora, which eliminates a significant proportion of pollutants entering natural water bodies and, thus, they contribute to the improvement of the water quality.

Phytoremediation is a set of methods of purification of water, soils, and even atmospheric air, using plant groups [1, 2]. We examined the application of this method for water treatment in our study.

The "plant groups" are understood as the higher aquatic vegetation (macrophytes) under. Their vital activity occurs only in the aquatic environment (submerged plants, floating ones, etc.) or partially in aquatic environments (air-aquatic plants, etc.). There are about 300 species of HAP, which are involved in the formation of the water quality differently, in the flora of the Central European countries. The main of them include cane, reedmace, pondweed, flowering rush, and others.

Thus, the treatment capacity of treatment plants (created artificially or by adapting to natural conditions) depends largely on the presence of HAP in their ecosystem. These plants become a reliable barrier to pollution, preventing them from entering rivers and lakes.

It becomes relevant to create a methodological approach to support managerial decision-making on the choice of phytoremediation technology for wastewater treatment plants when building them in a specific location under conditions of the required energy and resource-saving. Firstly, the approach based on a variety of factors and criteria will help to solve the problem of estimation of the result of a decision. Secondly, it will help to analyze alternatives or to determine the effectiveness of individual steps in the decision-making process during the selection and implementation of priority water treatment technologies.

\section{Literature review and problem statement}

Papers [1,2] presented basic technologies of phytoremediation, such as botanical sites, bioengineering facilities, and bio plateau. The papers showed their constructive implementation only. The authors of the papers did not analyze the advantages and disadvantages of each technology, which complicated the use of the given information for the choice of technology for implementation in specific settlements.

The authors of work [3] studied features of the use of plants (directly or indirectly) for the recovery of polluted soil or water. They determined that the phytoremediation method became the more economical, non-invasive, and generally available way to eliminate environmental pollution.

A small natural habitat or a size of plants, which exhibit restorative potential, and a lack of ability of native plants to tolerate, detoxify and accumulate pollutants can limit the widespread use of phytoremediation so the question remained unresolved. There is also a need to expand the list of criteria used to select appropriate phytoremediation technologies according to features of a particular terrain.

The authors of paper [4] determined that, with proper planning, recovery through the use of phytoremediation can be a useful tool for improvement of the quality of water of natural ecosystems in agricultural areas. The work proposed a methodology for the selection of wetland restoration sites to improve wastewater from irrigated agricultural land discharged into the Flumen River (Ebro River Valley, Northern Spain).

A preliminary study of the physical and chemical characteristics of the Flumen River and its apportionment identified nitrates as a key characteristic of the water quality in terms of data variability. The methodology consisted of five steps, which covered scientific, technical, social, and economic criteria. But the question of the development of a common approach to unify and standardize different techniques remained unresolved.

The authors of work [5] determined that wetlands in Europe still cover large areas in the northern part of the continent although $80 \%$ of the original area was lost over the past millennium. The wetlands of Europe are valuable because of their biodiversity and ecosystem value. The Ramsar Convention, EU directives, and national legislation on the protection of nature in different countries support their protection and restoration. The authors determined that it is necessary to intensify these actions to stop further deterioration of the resource and its many services. One should take into account the ecosystem capabilities of wetlands when making managerial decisions on land and water use. However, the question of the choice of an optimal, alternative technology that would take into account natural and socio-economic features of wetlands in their use remained unresolved.

The authors of work [6] stated that heavy metals are the most serious environmental pollution for now. Heavy metals have toxic effects on human health and cause several serious diseases. People use several methods to remove heavy metals from the environment, but these methods have limitations such as high cost, short duration of operation, logistical problems, and mechanical complexity. One can use phytoremediation as an alternative solution for the removal of heavy metals due to its advantages as a cost-effective and natural technology based on the use of natural landscape conditions and additional structures. The authors identified several plants, which have high potential as a bio-accumulator of heavy metals, based on the research. It is possible to use them for the process of phytoremediation of heavy metals. However, the issue of the development of an approach for the choice of an appropriate technological solution of phytoremediation in specific settlements remained unresolved.

The authors of paper [7] showed the problem of water pollution as a serious problem using an example of Lebanon. 
Loads of heavy pollutants and nutrients, heavy metals, and organic pollutants can be very damaging to human health and harm aquatic life and ecosystems. We consider phytoremediation a sustainable and very effective method of water purification in natural and artificially created wetlands. However, there is a very limited number of studies on the role of plants in the process of recultivation and features of an approach with the use of the priority phytoremediation technology.

The authors of paper [8] defined wetlands as a sanitary technology that utilizes natural removal mechanisms provided by vegetation, soil, and associated microbial populations. The authors provided a sufficiently large list of criteria, but they did not describe how to apply them in justification of a managerial decision on the choice of appropriate technology.

The authors of work [9] attempted to apply an integrated imitation model of phytoremediation in making managerial decisions on the use of natural processes of self-purification. They did it on the example of a water supply system, not a drainage system, which has significant features. In addition, the model did not take into account the features and conditions of specific territories of settlements and their social components.

All the above allow us to suggest that phytoremediation can have significant advantages over traditional water treatment technologies. However, it is necessary to carry out additional studies on the choice of a specific phytoremediation technology to realize its capabilities fully before designing treatment plants. It is also necessary to use the information of different professional directions such as environmental direction, biological direction, urban direction, social and economic ones. Therefore, it is advisable to carry out a study dedicated to the development of a methodological approach, which will give a possibility to consider this information in the choice of a phytoremediation technology for implementation in a particular settlement.

\section{The aim and objectives of the study}

The objective of the study is to develop a methodological approach to define a priority phytoremediation technology (PT) for the treatment of various types of wastewater (WW) from industrial, residential, and other settlements using the method of hierarchy analysis (MAI).

To achieve the set aim, the following tasks have been solved:

- the construction of a hierarchical model of factors, which influence the choice of a priority PT, and revealing of the procedure of its analysis by MAI;

- the testing of the devised methodological approach for determining the priority PT for the characteristic objects of a settlement.

\section{Construction of a hierarchical model of factors, which influence the choice of a priority PT, and revealing the procedure of its analysis by MAI}

The authors of work $[10,11]$ proposed the implementation of three sequent stages by MAI:

1) construction of a hierarchical model of comparison of elements of the task;

2) construction of a hierarchy of matrices of comparisons for elements of each level of the hierarchy by experts and definition of local priorities (weight coefficients) of elements for them, as well as the calculation of an index and conformity relation of expert matrices;

3 ) determination of global priorities of elements of each level starting with the second one, calculation of indices, and conformity relations of their expert matrices and selection of the best technology for implementation.

Stage 1. Construction of a hierarchical model of comparison of task elements. We took into account the following criteria in construction of the hierarchical model:

- the input and output future conditions of using the phytoremediation technologies, that is, the environmental and social features of the environment under which people exploit them;

- the geographical, soil-climatic, and economic features of a settlement, where we plan to use wastewater treatment plants built by the selected technology;

- the specific requirements for phytoremediation technologies as an object of the study.

The model included six levels (Fig. 1).

We defined the objective: "Improvement of ecological and social safety of surface water bodies through the introduction of phytoremediation technologies for treating all categories of wastewater" and six hierarchical levels, accordingly, at level 1 of the model. We took into account the parameters of wastewater for treatment according to the selected technology (elements of level 2):

$-B_{x} 1$ - a mode of wastewater movement;

$-B_{x} 2-\mathrm{pH}$ value, chemical oxygen demand (COD) and biological oxygen consumption (BOC) in wastewater;

$-B_{x} 3$ - the amount of suspended substances;

$-B_{x} 4$ - the amount of oil products;

$-B_{x} 5$ - the amount of heavy metals;

$-B_{x} 6$ - the number of surfactants;

$-B_{x} 7$ - an amount of bacterial contamination;

$-B_{x} 8$ - the number of radioactive elements.

At level 3, we took into account the requirements for surface water bodies (SWB) that will receive wastewater after treatment and the level of problems of residents living near a water body and using its water. The requirements were baselines. The treatment system had to maintain (improve) them: $B_{\text {inc }} 1$ - reservoirs of economic and drinking purpose; $B_{\text {inc }} 2$ - fish farms; $B_{\text {inc }} 3$ - reservoirs of complex purpose; $B_{\text {inc }} 4$ - living conditions of residents.

At level 4, we took into account the circumstances in the city where one planned to build treatment plants using the selected technology: OM1 - availability of free space for construction; OM2 - the presence of terrain inclination; $O M 3$ - a depth of groundwater level; OM4 - the presence of specific conditions (wetlands with HAP shrubs, ravines, lakes); OM5 - financing opportunities.

At level 5, we took into account factors, which influenced the choice of phytoremediation technology directly. They were presented in the form of design and operational requirements for the selected technology: $F 1$ - availability of HAP; $F 2$ - duration of work during a year; $F 3$ - load dynamics; $F 4$ - requirements for the thickness of a soil filter at the base; F5 - the ability to work without significant operating costs.

Level 6 was the last one. It gave alternative solutions, such as the types of phytoremediation technologies for building treatment plants: PT1 - botanical sites; PT2 - bioengineering facilities; PT3 - a bio-plateau; PT4 - a combination of technologies.

Table 1 describes the characteristics of phytoremediation technologies. 
Table 1

The characteristics of phytoremediation technologies

\begin{tabular}{|c|c|c|}
\hline $\begin{array}{c}\text { Type of technology and its design } \\
\text { features }\end{array}$ & Advantages & Disadvantages \\
\hline $\begin{array}{l}\text { Botanical sites }[1,2] \text {. Shallow } \\
\text { water areas of arbitrary configu- } \\
\text { ration with natural HAP thickets } \\
\text { of natural origin, ranging from } \\
\text { several to tens of hectares, creat- } \\
\text { ed in the existing depressions of } \\
\text { terrain or especially demolished } \\
\text { territories. }\end{array}$ & $\begin{array}{c}\text { no usable land is required } \\
\text { construction does not require significant capital } \\
\text { investment; } \\
\text { operates for decades with minimal operating costs } \\
\text { (purification is ongoing due to existing natural } \\
\text { biocenosis). }\end{array}$ & $\begin{array}{l}\text { the possibility of stagnant occurrence } \\
\text { zones and re-pollution due to insufficient control- } \\
\text { lability of treatment processes; } \\
\text { the structure is sensitive to the flow of incoming } \\
\text { water due to imperfect regulation system; } \\
\text { the efficiency of reverse water treatment is lower } \\
\text { than other technologies by the major components } \\
\text { of pollution since the treatment takes place in the } \\
\text { surface layer of water only. }\end{array}$ \\
\hline $\begin{array}{l}\text { Bioengineering structures [1, 12]. } \\
\text { Wastewater treatment plants } \\
\text { that integrate the main elements } \\
\text { of soil treatment facilities with } \\
\text { hydrobiocenoses of bio plateau or } \\
\text { ponds with planted HAP. A dis- } \\
\text { tinctive feature of structures is } \\
\text { the artificially formed biocenosis, } \\
\text { its quantitative and qualitative } \\
\text { characteristics of constituent } \\
\text { components form under the } \\
\text { direct and indirect influence of } \\
\text { HAP. }\end{array}$ & $\begin{array}{l}\text { high treatment indicators - the treatment goes } \\
\text { both in the horizontal plane - through HAP thick- } \\
\text { ets, and in the vertical plane - through a layer of } \\
\text { the filtering thickness saturated with rhizomes of } \\
\text { plants, microflora, and algae; } \\
\text { structures have much larger technical resource } \\
\text { than structures using traditional treatment tech- } \\
\text { nologies; } \\
\text { the availability of methods of engineering control } \\
\text { provides: } \\
\text { a wide range of costs and composition of wastewa- } \\
\text { ter at the entrance to structures; } \\
\text { possibility of the application under different } \\
\text { climatic conditions; } \\
\text { has a more stable treatment performance through- } \\
\text { out a year. }\end{array}$ & $\begin{array}{l}\text { requires capital costs for construction of struc- } \\
\text { tures (however lower than traditional treatment } \\
\text { systems); } \\
\text { requires exploitation costs for the maintenance of } \\
\text { personnel required to provide design performance. }\end{array}$ \\
\hline $\begin{array}{l}\text { Bio plateau }[1,13] \text {. It consists } \\
\text { of one or more filtration and } \\
\text { surface blocks located on a slope } \\
\text { of the terrain in such a way as } \\
\text { to provide a flowing stream of } \\
\text { treated water. Bioplateaux may } \\
\text { include sites (artificial) planned } \\
\text { according to the inclination of } \\
\text { terrain, planted HAP, natural } \\
\text { areas covered by HAP included } \\
\text { in the treatment plant as a treat- } \\
\text { ment unit. }\end{array}$ & $\begin{array}{l}\text { the ability to adjust the depth of a water flow } \\
\text { provides suitable conditions for water treatment, } \\
\text { it has better performance than the technology of } \\
\text { botanical sites; }\end{array}$ & $\begin{array}{l}\text { seasonality of work, due to the insignificant } \\
\text { depth, there is a likelihood of freezing of a struc- } \\
\text { ture in winter, which will reduce the efficiency of } \\
\text { its treatment; } \\
\text { a failure to observe design parameters of operation } \\
\text { can lead to odors, accumulation of hydrogen } \\
\text { sulfide, and other toxicants, reducing the activity } \\
\text { of microorganisms, which, in turn, affects the } \\
\text { efficiency of wastewater treatment adversely. }\end{array}$ \\
\hline $\begin{array}{l}\text { Combination of technologies [2]. } \\
\text { A combination of previous } \\
\text { technologies, depending on input } \\
\text { and output conditions for the } \\
\text { creation of phytoremediation } \\
\text { plants. }\end{array}$ & \multicolumn{2}{|c|}{ The advantages and disadvantages depend on the types of technologies combined. } \\
\hline
\end{tabular}

The formed hierarchical model of comparison (Fig. 1) contains no more than nine elements for the eligible study at each level of the hierarchy. This meets the requirements [11].

The implementation of MAI 2 and 3 stages is rather formalized $[10,11]$ and has a computerized implementation. Therefore, we noted only the specific features of these stages.

Stage 2. Construction of each level of the hierarchy of comparison matrices for elements by experts, determination of local priorities of elements for them, and calculation of the index and conformity relation of expert matrices.

Features of stage implementation:

- it is necessary to involve an expert team to construct comparison matrices by elements of each level of the hierarchy. These are specialists of environmental, town-planning, social, and economic directions of municipal authorities of a specific settlement, industrial, residential, and military objects, where we plan to build treatment plants. Experts create a square inverse symmetry matrix of judgments by their profile (Fig. 1). These matrices are basis data for the implementation of stage 2;

- in the construction of these matrices, it is advisable to use the classical scale of conversion of expert judgment into a value of the weight coefficient of the first indication relative to the second one, where the coefficients vary from 1 to 9 [11].

Stage 3: Determination of the global priorities of elements of each level, starting with the second one, calculation of indices and conformity relations of their expert matrices, and a choice of the best technology for implementation.

The peculiarity of the stage implementation is that it is necessary to perform the calculation of local and global priorities (weight coefficients) of elements and determination of an index and a conformity relation of the corresponding expert matrices with the accuracy of 0.001 as recommended by work [11]. 
Levels of hierarchy

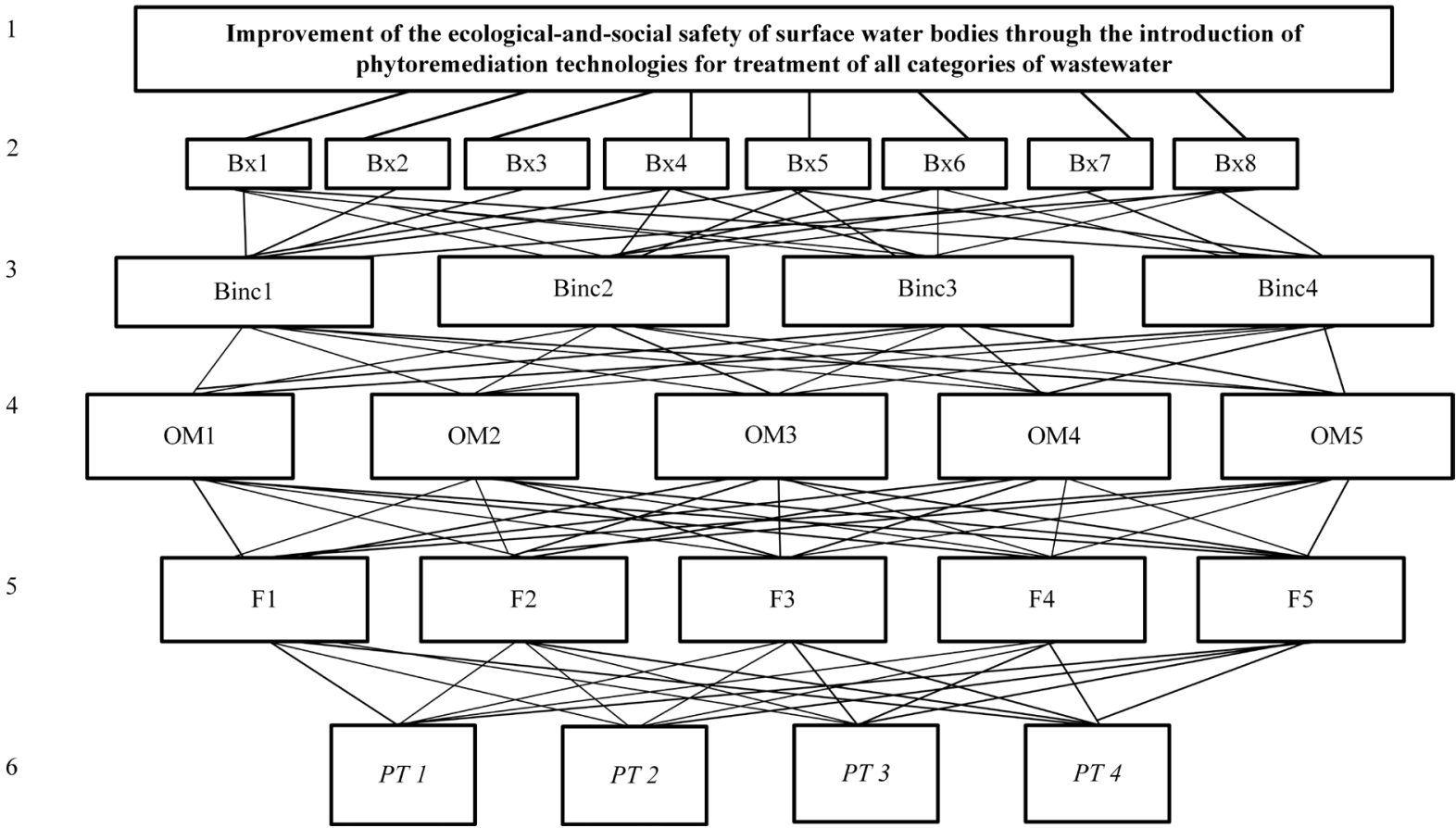

Fig. 1. The hierarchy of the choice of environmentally-and-socially safe phytoremediation technologies

Therefore, the chosen option of the phytoremediation technology will be the best for implementation from the point of view of peculiarities of the environment, a populated area where it will operate, and specific requirements for this type of technology. In addition, we should note that this option makes it possible to use the information of different types, such as direct measurement data, forecasts, and expert estimates.

\section{Testing the devised methodological approach for} determining the priority PT for the characteristic objects of a settlement.

Let us consider examples of the application of the developed methodological approach for the choice of PT at 3 Ukrainian objects. They are an enterprise of LLC "Skhid-Ruda", Zhovti Vody city; a residential building, Nova Husarivka vil., Kharkiv oblast; a city hospital, Zolochiv city, Kharkiv oblast. Each of the objects of the study has its specific characteristics in terms of wastewater parameters, availability of free space for construction, living conditions of residents, etc. For example, objects have the following characteristics of wastewater:

- at the industrial enterprise - the most intensive movement of wastewater, the increased quantitative values of $\mathrm{pH}$, COD and BOC, and radioactivity;

- at the residential development - significant values of $\mathrm{pH}, \mathrm{COD}$ and BOC, oil products and suspended solids;

- at the city hospital - the presence of an infectious compartment leads to bacterial contamination.

The tasks of the study for each object are:

- selection of the priority PT for implementation on a specific object;

- analysis of priorities of elements of a decision by the descending levels of the hierarchy, which gives the possi- bility to understand how we get one or another value of the decisions. The results of the analysis are necessary in case of variations in parameters of treatment plants during their design.

We implemented all three stages of MAI in the study of the objects. The hierarchy, shown in Fig. 1, became the basis for their implementation. We involved specialists in relevant city councils and objects as experts. Tables $2-6$ give the intermediate results of their work at different levels of the hierarchy.

Table 2

The results of pairwise comparisons of the level of subcriteria of input parameters of the treatment system $\left(B_{x} 1-B_{x} 8\right)$

\begin{tabular}{|c|c|c|c|}
\hline \multirow{2}{*}{ Criteria } & $\begin{array}{c}\text { «khid-Ru- } \\
\text { da», Zhovti } \\
\text { Vody }\end{array}$ & $\begin{array}{c}\text { Residential building, } \\
\text { Nova Husarivka vil. }\end{array}$ & $\begin{array}{c}\text { City hospital, } \\
\text { Zolochiv }\end{array}$ \\
\cline { 2 - 4 } & $W /$ weight & $W /$ weight & W/weight \\
\hline$\left(B_{x} 1\right)$ & 0.07611 & 0.1452 & 0.0877 \\
\hline$\left(B_{x} 2\right)$ & 0.1251 & 0.1724 & 0.1215 \\
\hline$\left(B_{x} 3\right)$ & 0.1107 & 0.1212 & 0.1191 \\
\hline$\left(B_{x} 4\right)$ & 0.1066 & 0.1316 & 0.1006 \\
\hline$\left(B_{x} 5\right)$ & 0.1066 & 0.1125 & 0.1085 \\
\hline$\left(B_{x} 6\right)$ & 0.1107 & 0.092 & 0.1324 \\
\hline$\left(B_{x} 7\right)$ & 0.1107 & 0.1046 & 0.1954 \\
\hline$\left(B_{x} 8\right)$ & 0.2536 & 0.1205 & 0.1349 \\
\hline$B Y$ & 0.01 & 0.03 & 0.03 \\
\hline$I Y$ & 0.02 & 0.04 & 0.04 \\
\hline$\lambda_{\max }$ & 8.0 & 8.0 & 8.0 \\
\hline$W_{\text {average }}$ & 1 & 1 & 1 \\
\hline
\end{tabular}




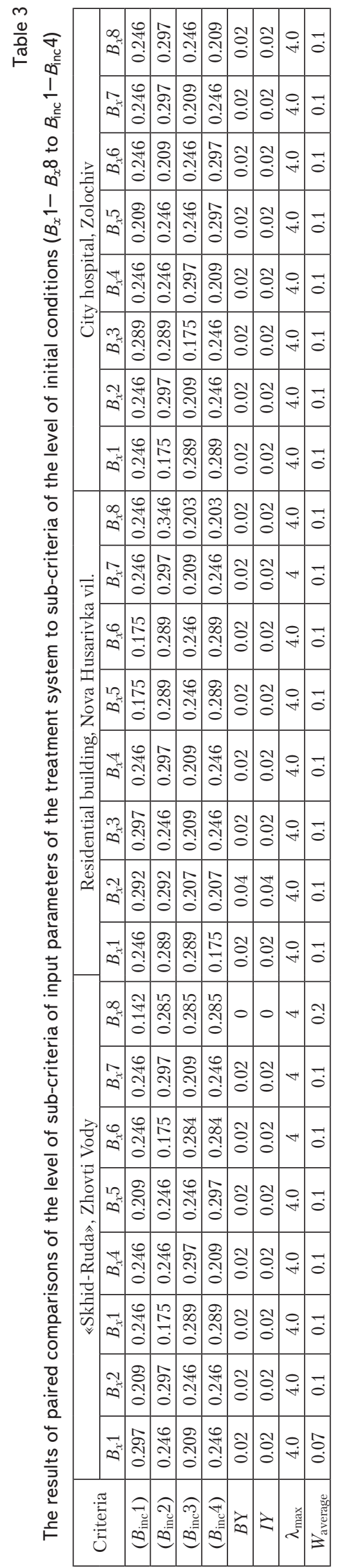

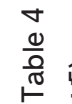

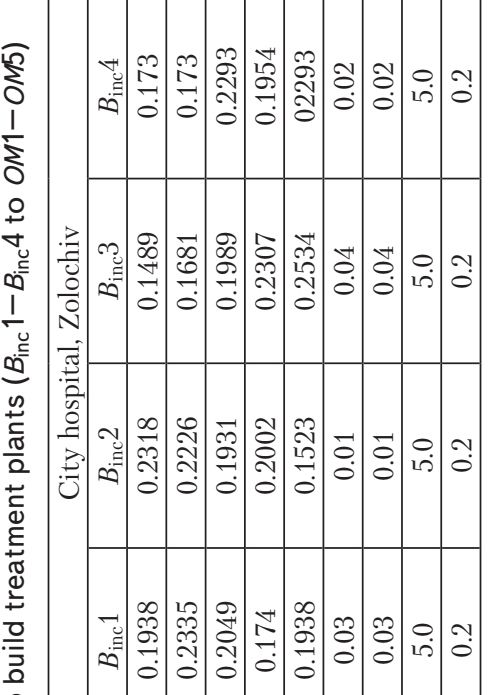

$\circ$

뜬

(

3

迹

$\frac{0}{4}$$$
\text { 范 }
$$

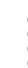$$
\text { 疍 }
$$

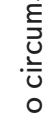$$
\text { is }
$$

돈

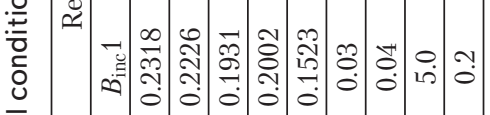

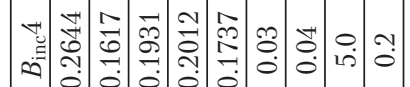
$\overrightarrow{\overrightarrow{5}}$

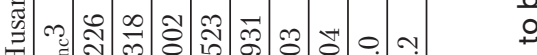

ט.

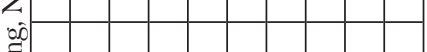

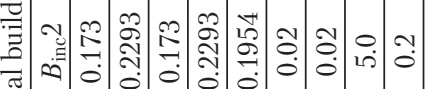

:

प

r.

$\stackrel{\oplus}{+}$

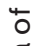

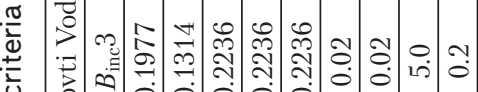

离

ज

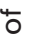

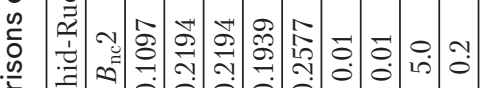

离

हั่

:

$\frac{\sqrt{\circ}}{\sqrt{\circ}}$

$\stackrel{5}{5}$

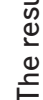

는 $\frac{0}{0} \cdot \frac{9}{0}$ $\stackrel{9}{ \pm}$

要

要

(5)

to

$\frac{4}{0}$

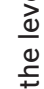

$\stackrel{5}{\circ}$

雍

$\frac{\pi}{2}$

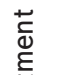

蛋

을

든

$\sum \frac{1}{4}$

30

$\frac{ \pm}{3} \aleph^{\frac{1}{3}}$

$\stackrel{+\infty}{\omega} \frac{1}{\infty}$

응

造

趈

क

产

$\frac{4}{0}$

$\frac{2}{4}$

.

(5)

章

ज

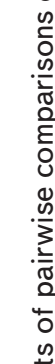

:

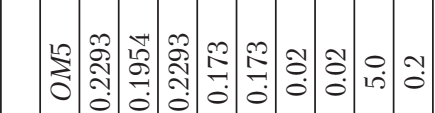

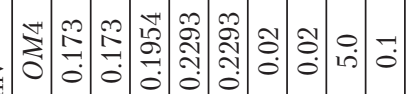

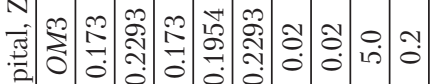

-

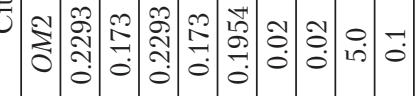

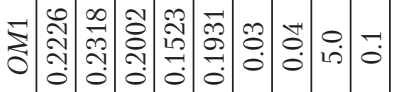

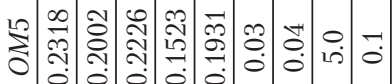

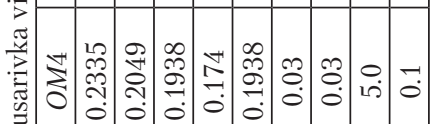

言

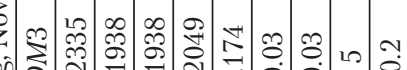

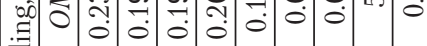

.

节 离

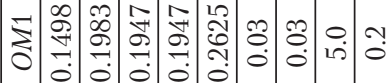

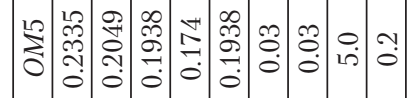

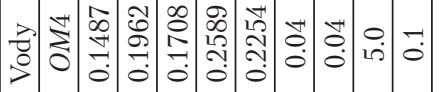

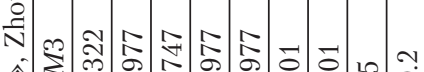

合

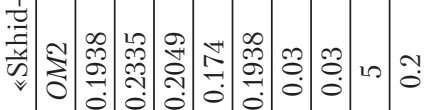

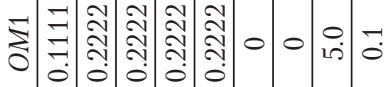

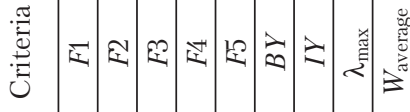


Table 6

The results of pairwise comparisons of sub-criteria of the level of factors, which influence the choice of $P T$ to the level of alternatives $(F 1 \ldots F 5$ to $P T 1 \ldots 4)$

\begin{tabular}{|c|c|c|c|c|c|c|c|c|c|c|c|c|c|c|c|}
\hline \multirow{2}{*}{$\begin{array}{c}\text { Crite- } \\
\text { ria }\end{array}$} & \multicolumn{5}{|c|}{ «Skhid-Ruda», Zhovti Vody } & \multicolumn{5}{|c|}{ Residential building, Nova Husarivka vil. } & \multicolumn{5}{|c|}{ City hospital, Zolochiv } \\
\hline & $F 1$ & $F 2$ & $F 3$ & $F 4$ & $F 5$ & $F 1$ & $F 2$ & $F 3$ & $F 4$ & $F 5$ & $F 1$ & $F 2$ & $F 3$ & $F 4$ & $F 5$ \\
\hline$P T 1$ & 0.3952 & 0.2463 & 0.3952 & 0.2979 & 0.1571 & 0.2463 & 0.2463 & 0.2463 & 0.2096 & 0.1571 & 0.1682 & 0.1429 & 0.1404 & 0.2463 & 0.1692 \\
\hline$P T 2$ & 0.239 & 0.2979 & 239 & 0.2096 & 0.3191 & 0.3465 & 0.2979 & 0.2979 & 0.2979 & 0.3191 & 0.1976 & 0.2857 & .239 & 0.2463 & 0.2046 \\
\hline$P T 3$ & 0.1976 & 0.2096 & 0.1976 & 0.2463 & 0.281 & 0.2036 & 0.2096 & 0.2463 & 0.2463 & 0.281 & 0.239 & 0.2857 & 0.2308 & 0.2979 & 0.2879 \\
\hline PT4 & 0.1682 & 0.2463 & 0.1682 & 0.2463 & 0.2428 & 0.2036 & 0.2463 & 0.2096 & 0.2463 & 0.2428 & 0.3952 & 0.2857 & 0.3397 & 0.2096 & 0.3383 \\
\hline$B Y$ & 0.02 & 0.02 & 0.02 & 0.02 & 0.04 & 0.02 & 0.02 & 0.02 & 0.02 & 0.04 & 0.02 & 0 & 0.02 & 0.02 & 0.02 \\
\hline$I Y$ & 0.02 & 0.02 & 0.02 & 0.02 & 0.03 & 0.02 & 0.02 & 0.02 & 0.02 & 0.03 & 0.02 & 0 & 0.02 & 0.02 & 0.02 \\
\hline$\lambda_{\max }$ & 4.0 & 4.0 & 4.0 & 4.0 & 4.0 & 4 & 4.0 & 4.0 & 4.0 & 4.0 & 4.0 & 4.0 & 4.0 & 4.0 & 4.00 \\
\hline$W_{\text {average }}$ & 0.1 & 0.2 & 0.1 & 0.2 & 0.2 & 0.1 & 0.1 & 0.1 & 0.1 & 0.2 & 0.2 & 0.2 & 0.1 & 0.1 & 0.1 \\
\hline
\end{tabular}

We performed all calculations on PC with an accuracy of 0.001 recommended by works [10,11] using the appropriate commands in the MAI (MPriority 1.0) environment.

We calculated the quantitative value of the global priority for each option of $P T$ based on the calculations of the investigated objects. The largest value of this indicator is an option of $P T$ recommended for implementation on the corresponding object (Fig. 2-4).

Fig. 2 shows the results of calculations for LLC "Skhid-Ruda", Zhovti Vody city.

The overall conformity estimate $(I Y)$ of the hierarchy was $0.02696<0.1$ ( 0.1 was the critical value of the conformity indicator. The smaller value of the estimate indicated the reliability of the obtained data [10,11]). PT1 - botanical sites received the highest value of global priority (0.2949).

One can trace a change in the current priorities by the descending industrial hierarchy in Fig. 2.
The input parameters of wastewater were at the same relatively low level, except for their intensity of movement $\left(B_{x} 1=0.7611\right)$ and a number of radioactive elements $\left.B_{x} 8=0.2536\right)$. One can consider their influence on different types of surface water bodies (level 3 of the hierarchy) as equal.

Treatment of wastewater with the indicated parameters requires significant capital expenditures (financing availability $O M 5=0.2145$ ). Expenditure can decrease in the presence of sufficient inclination of the terrain $(O M 2=0.2002)$ and considerable depth of the groundwater level $(O M 3=0.2113)$.

All factors of level 5 of the hierarchy - design and operational requirements for $P T$ - had approximately the same impact on the choice of priority technology (PT1 - botanical sites), except for the availability of HAP. Its value of the local priority was only $F 1=0.1811$.

Improvement of the ecological-and-social safety of surface water bodies through the introduction of phytoremediation technologies for the treatment of all categories of wastewater, LCC "Skhid-Ruda", Zhovti Vody city

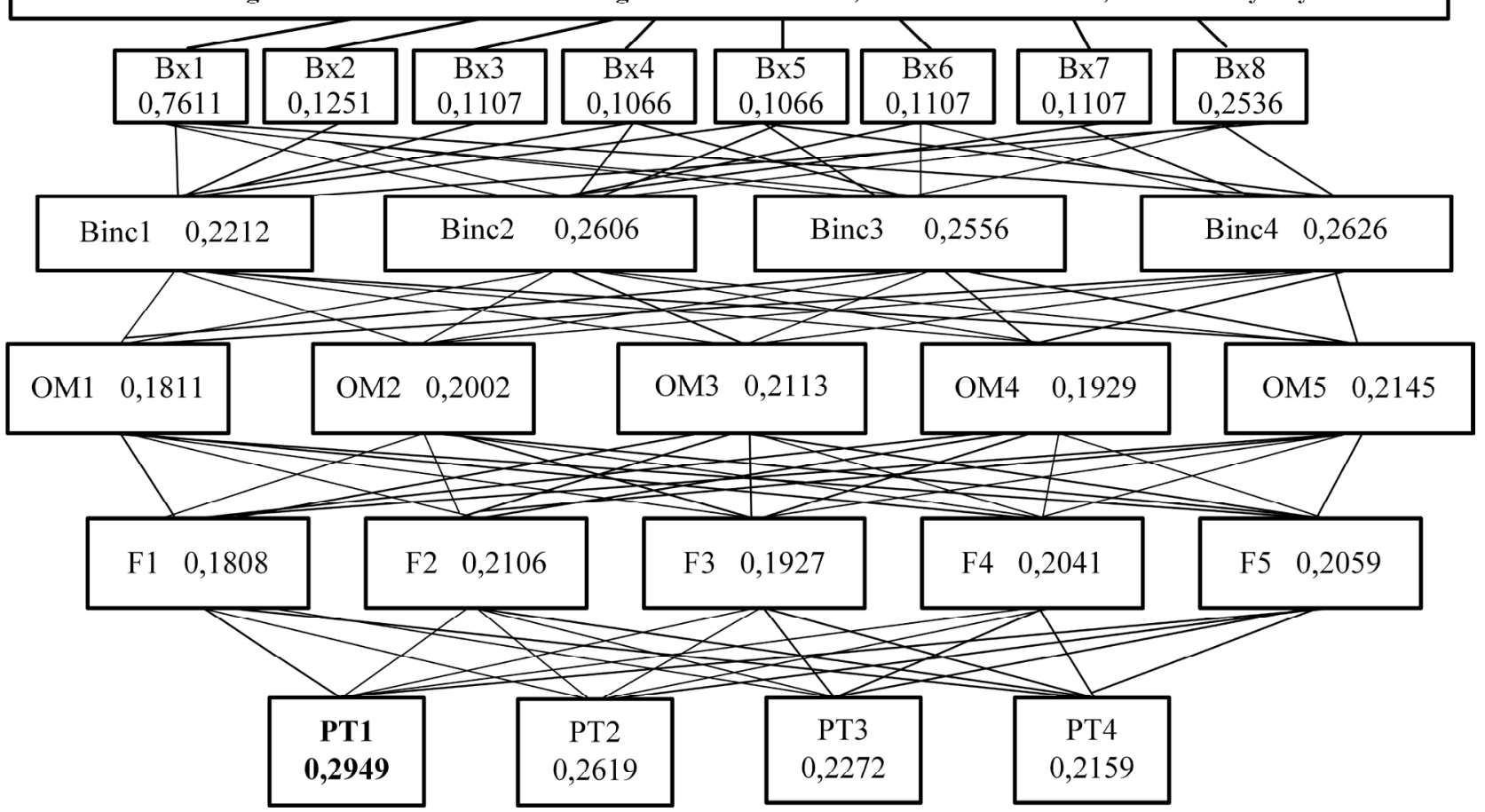

Fig. 2. The hierarchy of the choice of the most environmentally-and-socially safe $P T$ for the enterprise of LLC “Skhid-Ruda”, Zhovti Vody city 
Improvement of the ecological-and-social safety of surface water bodies through the introduction of phytoremediation technologies for the treatment of all categories of wastewater of the residential building, Nova Husarivka vil.

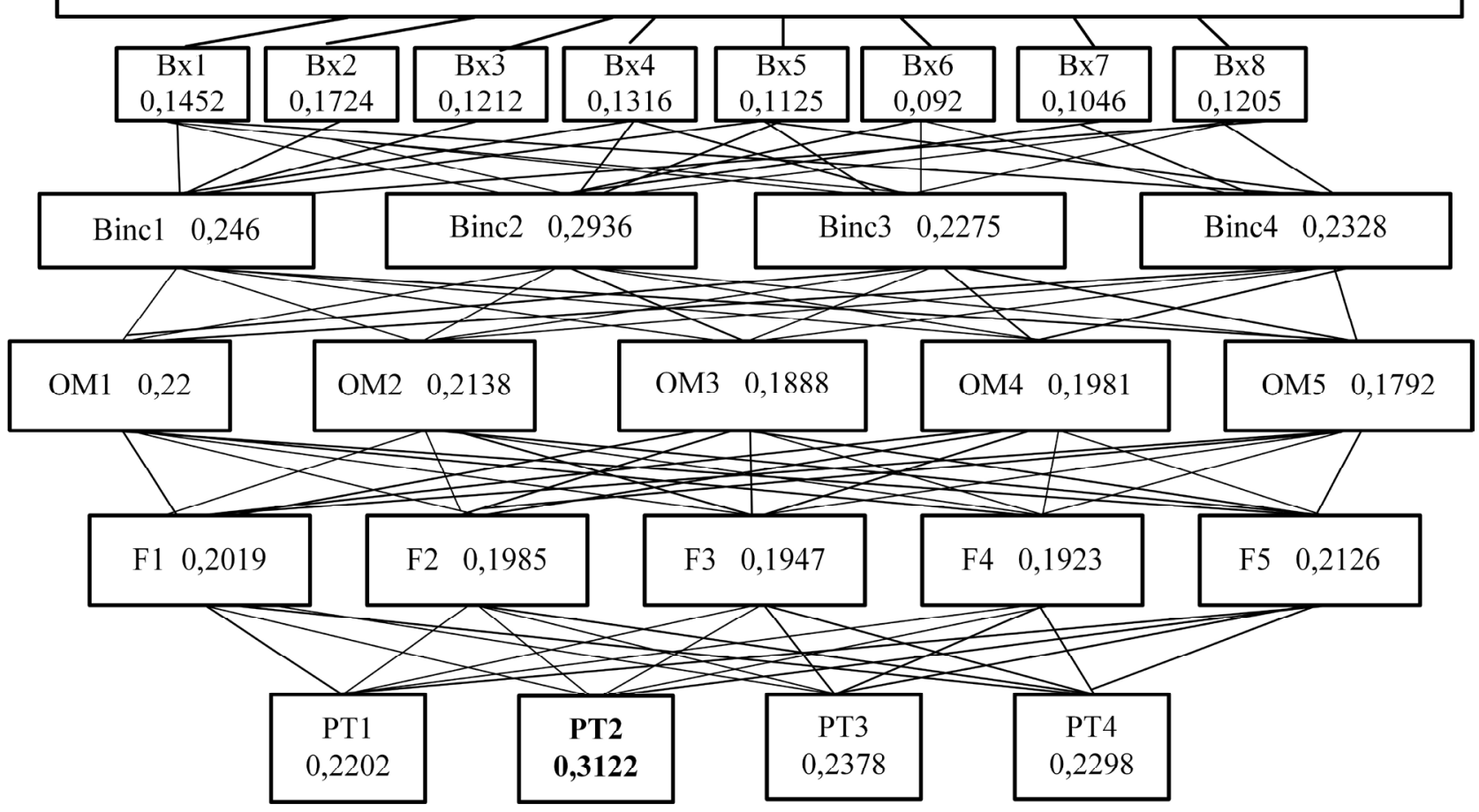

Fig. 3. The hierarchy of the choice of the most environmentally-and-socially safe $P T$ of the residential building, New Husarivka vil.

The experts proposed to use the former tailing dump of the mining and processing plant as a botanical site according to the results of the study. Its surface was covered with HAP, such as reeds and reedmace, completely. Compacted loam covered dams, which divided the tailing dump into separate sections. There was a bypass channel for interception of a surface runoff along the perimeter of the tailing dump. The tailings dump should receive mine water in the volume of $250-400 \mathrm{~m}^{3} / \mathrm{h}$ in the presence of high content of radionuclides and carry out their purification to the norms of water quality for municipal purposes.

Fig. 3 shows the results of calculations for the residential building, New Husarivka village. The overall conformity estimate $(I Y)$ for the hierarchy was $0.02707<0.1$. A bioengineering structure received the highest value with a rather small margin from other technologies PT2 (0.3122) in accordance with the numerical values of the global priorities.

One can trace a change in the current priorities for the des-cending hierarchy for the particular residential building in Fig. 3.

The characteristic initial parameters of wastewater for such an object are significant values of $\mathrm{pH}, \mathrm{COD}$, and BOC $\left(B_{x} 2=0.1724\right)$, a number of oil products $\left(B_{x} 4=0.1316\right)$ and suspended substances $\left(B_{x} 3=0.1212\right)$. In addition, one should note the presence of a significant value of wastewater movement $\left(B_{x} 1=0.1452\right)$. The composition of the parameters can have the most negative impact on the reservoirs of fish farms $\left(B_{\text {inc }} 2=0.2936\right)$.

Two factors facilitate the successful placement of treatment plants on a site. They are $O M 1$ - availability of free space for construction $(O M 1=0.2200)$ and $O M 2$ - the presence of a terrain inclination $(O M 2=0.2138)$.

One can mark out the ability to work without significant operating costs $(F 5=0.2126)$ among the factors of structural and operational requirements for $P T$. The last factors at level 5 of the hierarchy had approximately the same impact on the choice of the priority technology ( $P T 2$ was a bioengineering structure).

Experts suggested placing a bioengineering structure at a site that had no hard covering and was not currently used on the farm. The layout and basic design parameters fit into the existing landscape conditions.

The selected technology will provide an environmentally friendly result in the treatment of contaminated water, and it allows a safe disposal of wastewater. The treatment on bioengineering structures has high values of indicators because its implementation proceeds both in the horizontal plane - through thickets of HAP and in the vertical plane - through a layer of filtering (gravel, sand) thicker, which is saturated with rhizomes of plants, microflora, and algae.

Fig. 4 shows the results of the calculations for the city hospital, Zolochiv city. The overall consistency estimate (IY) of the hierarchy was $0.01806<0.1$. The combination of technologies, PT4, received the highest value of the global priority (0.3159).

One can trace a change in the current priorities of the descending hierarchy for the Bioengineering structures hospital in Fig. 4.

The input wastewater parameters had significant bacterial contamination $\left(B_{x} 7=0.1954\right)$. In addition, one should note water pollution with surfactants $\left(B_{x} 6=0.1324\right)$ and radioactive elements $\left(B_{x} 8=0.1349\right)$. The mode of wastewater movement was not very significant $\left(B_{x} 1=0.0877\right)$ at this site. This composition of parameters can have the most negative impact on both reservoirs of the fish farm $\left(B_{\text {inc }} 2=0.2636\right)$ and the complex $\left(B_{\text {inc }} 4=0.2538\right)$ purpose. 


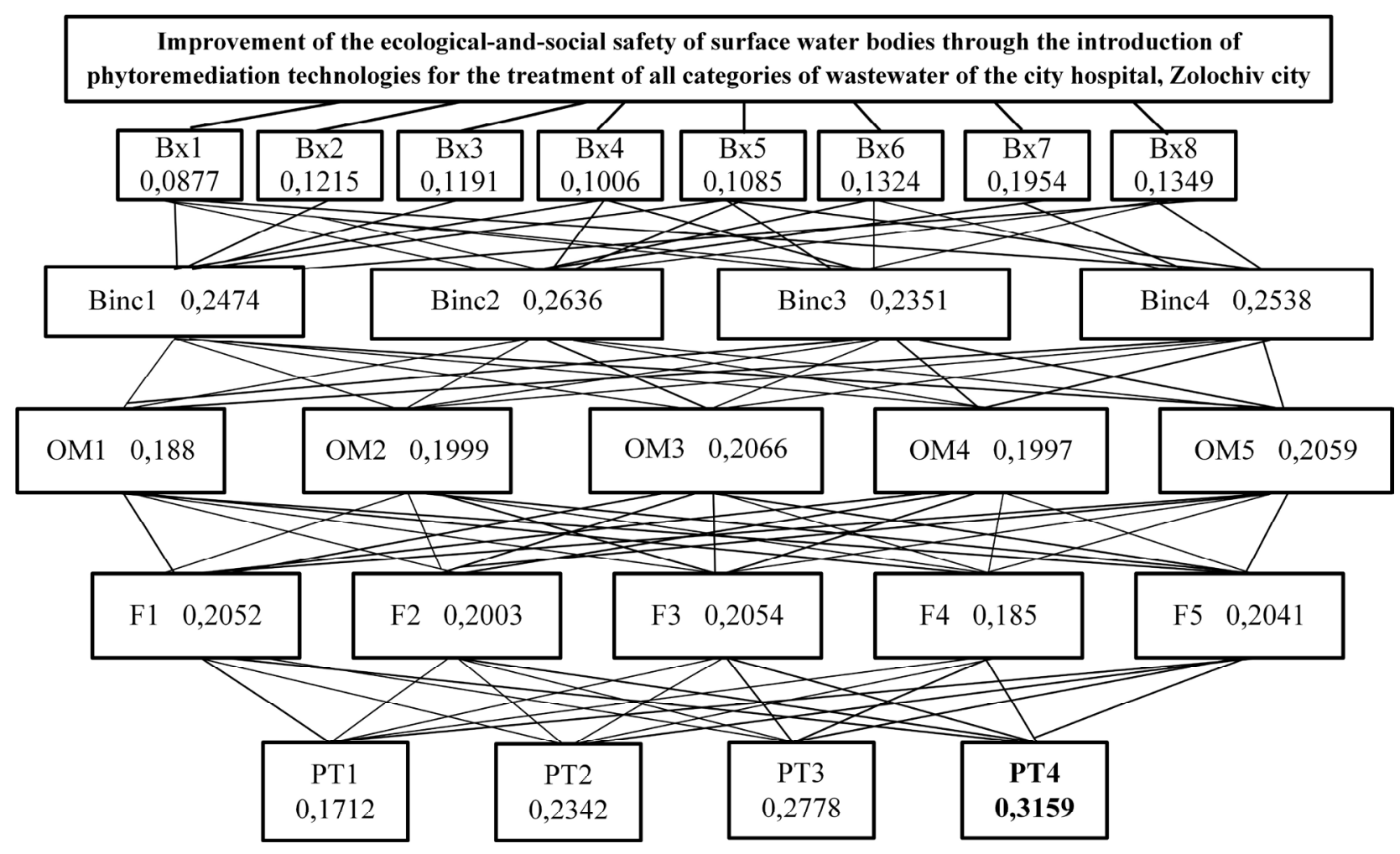

Fig. 4. The hierarchy of the choice of the most environmentally-and-socially safe $P T$ for the city hospital, Zolochiv city

Two factors can have a significant negative impact on the construction of treatment plants at an object: a low depth of groundwater $(O M=0.2066)$ and a lack of sufficient financing $(O M 5=0.2059)$.

The design and operational requirements for $P T$ (factors at level 5 of the hierarchy) had approximately the same effect on the choice of priority PT (PT4 - a combination of technologies), except the factor of the requirement for soil filter thickness at the base. The value of the local priority was only $F 4=0.1850$ for it. Indeed, a significant reduction in bacterial contamination does not depend on the thickness of the filtering in this case. One can achieve it through the use of HAP only.

Experts suggested building (adjusting) a cascade of three successive settling tanks and two (a combination of technologies) to treat wastewater from the hospital before discharging them into an existing hydropower network. Such protection will ensure the prevention of bacterial contamination entering a water body. Bacterial contamination and the suspended matter will be processed under the slow mode of motion of WW by biocenosis in settling tanks and Bioengineering structures due to biochemical processes occurring in cells of HAP, algae, and microorganisms, which promotes the growth of their biomass. A part of substances will get into the root system of HAP (reed) as a stock substance and will be used for the self-renewal of phytocenosis over the next growing cycle.

Regardless of phytoremediation technologies implemented in the design of treatment plants, they must remain under the supervision of specialists to optimize HAP groups after the start of their operation. It is possible to get the required degree of wastewater treatment when plants achieve the designed capacity. It takes about 2 years, as a rule. The duration of the start-up period depends on the development of HAP in them. This period is necessary for plants to grow underground and aboveground biomass. An area covered by plants in the waters of plants depends on their biomass. A plant achieves the highest degree of treatment when there are plants form dense thickets with a large number and $100 \%$ coverage area of HAP in plants.

\section{Discussion of results of studying the developed methodological approach}

The main result in the development of the methodological approach is the formed hierarchical model for comparison of elements of the problem (Fig. 1). It reflects the peculiarities of the drainage process, unlike the model given for water supply in work [9]. The model takes into account not only features of phytoremediation technologies, mainly biological but also conditions of specific sites, their environmental, social, economic, and territorial components. The use of an extended amount of information in the development of solutions increases the objectivity of their justification.

Obtaining the result has become possible due to the MAI method. We divided a difficult initial task into a series of simple ones applying the MAI method. It allowed us to involve experts in different professional fields. Experts could rely on both their experience, intuition, and objective data (direct measurements, predictions, and statistics).

It was impossible to develop a methodological approach without specifying data on $P T$ themselves. Papers $[1,2]$ introduced notions of only 3 of them. They were botanical sites, bioengineering structures, and bio plateaus. There were features of their constructive implementation shown. Our study added (Table 1) the fourth $P T$ to the list. It is a 
combination of technologies. In addition, we listed the advantages and disadvantages of each technology, so we could compare them.

It is possible to apply the formed hierarchical model repeatedly. All you must do is to fill it with expert data on different objects. It is possible to adjust the structure of the model if necessary.

We tested the developed methodological approach on three different objects of settlements, such as an industrial object, a residential building, and a hospital. Their data on priorities of elements of the 2nd (input WW parameters) and the 3rd (requirements for the state of SWO, which will receive wastewater after treatment, and a level of problems of residents, who live near a water object and using its water) levels of the hierarchy can serve as guidelines for the study of similar projects.

The conformity indicator was significantly lower than the critical level $(<0.1)$ in the individual matrices and the entire hierarchy for all objects studied (Tables 2-6). The results of the verification testify to the accuracy of the used expert data and the correctness of the solution of the problem of the choice of the priority phytoremediation technology for each object. In addition, we received new information on objects. It is the ratio of priorities of elements of the decision by the descending levels of the hierarchy. The results of this analysis are necessary in case of variation of parameters of treatment plants in their design.

Restrictions on the application of the developed methodological approach can be some difficulties in substantiating decisions, in particular, it is necessary to involve a trained group of specialists to organize the research. It is necessary to do the following: to select experts, assign them research tasks, organize pairwise comparisons, identify data conflicts, and more. It is possible to compensate for the disadvantage by involving this group to solve typical tasks repeatedly. The more objects a group will work on, the greater will be its experience in the application of the approach, that is, the approach becomes more effective.

Directions for the development of the study:

- MAI can test expert information for conformity using the index and the conformity relations for both individual matrices and the entire hierarchy. More sophisticated software tools, which implement MAI (Expert Choice, ПPAIC), appear. They provide an additional opportunity to identify the most inconsistent expert judgments. The transition to using the software will increase the efficiency of work with experts, which will increase the level of validity of management decisions;

- it is necessary to carry out a thorough analysis of each approbation of the developed methodological approach and to improve the proposed research tool according to its results constantly.

\section{Conclusions}

1. A hierarchical model has been constructed of those factors, which influence the choice of a priority technology of phytoremediation, and a procedure of its analysis by MAI has been devised. The model takes into account not only features of phytoremediation technologies (mainly biological ones) but also conditions of specific settlements, their environmental, social, economic, and territorial components. The use of extended information in the development of solutions increases the objectivity of their justification. It is possible to apply the formed hierarchical model repeatedly. All you must do is to fill it with expert data from different objects. It is possible to adjust the structure of the model if necessary.

2. The developed methodological approach was tested at three different objects of settlements. They are an industrial object, a residential building, and a hospital. We obtained the following:

- priority phytoremediation technologies for implementation on an object;

- results of the analysis of priorities of elements of the decision on the descending levels of the hierarchical model, which makes it possible to understand how one or another value of the decisions was obtained. These results are necessary in case of variation of treatment plant parameters in their design.

We calculated the conformity index in the individual matrices and the entire hierarchy for all the objects studied. The values of the indicator were below the critical level $(<0.1)$ in all cases. The verification results testify to the validity of the expert data used and the correctness of the solution of the problem of the choice of a priority phytoremediation technology for objects.

References

1. Beans, C. (2017). Core Concept: Phytoremediation advances in the lab but lags in the field. Proceedings of the National Academy of Sciences, 114 (29), 7475-7477. doi: https://doi.org/10.1073/pnas.1707883114

2. Dmitrieva, O. O., Teliura, N. O., Vasilenko, V. P. (2018). Implementation environmentally safe wastewater as an element of sustainable human settlements development Ukraine. Municipal economy of cities, 7 (146), 174-179. doi: https://doi.org/10.33042/25221809-2018-7-146-174-179

3. Arthur, E. L., Rice, P. J., Rice, P. J., Anderson, T. A., Baladi, S. M., Henderson, K. L. D., Coats, J. R. (2005). Phytoremediation - An Overview. Critical Reviews in Plant Sciences, 24 (2), 109-122. doi: https://doi.org/10.1080/07352680590952496

4. Comín, F. A., Sorando, R., Darwiche-Criado, N., Garcнa, M., Masip, A. (2014). A protocol to prioritize wetland restoration and creation for water quality improvement in agricultural watersheds. Ecological Engineering, 66, 10-18. doi: https:// doi.org/10.1016/j.ecoleng.2013.04.059

5. Verhoeven, J. T. A. (2014). Wetlands in Europe: Perspectives for restoration of a lost paradise. Ecological Engineering, 66, 6-9. doi: https://doi.org/10.1016/j.ecoleng.2013.03.006

6. Sumiahadi, A., Acar, R. (2018). A review of phytoremediation technology: heavy metals uptake by plants. IOP Conference Series: Earth and Environmental Science, 142, 012023. doi: https://doi.org/10.1088/1755-1315/142/1/012023 
7. Ghanem, H., Chalak, L., Baydoun, S. (2019). Phytoremediation of Lebanese polluted waters: a review of current initiatives. MATEC Web of Conferences, 281, 03007. doi: https://doi.org/10.1051/matecconf/201928103007

8. Maiga, Y., von Sperling, M., Mihelcic, J. (2017). Constructed Wetlands. Global Water Pathogen Project. doi: https:// doi.org/10.14321/waterpathogens.66

9. Morley, M. S., Vitorino, D., Behzadian, K., Ugarelli, R., Kapelan, Z., Coelho, S. T., Do Céu Almeida, M. (2015). Decision support system for the long-term city metabolism planning problem. Water Supply, 16 (2), 542-550. doi: https://doi.org/10.2166/ws.2015.167

10. Saaty, T. L., Ergu, D. (2015). When is a Decision-Making Method Trustworthy? Criteria for Evaluating Multi-Criteria Decision-Making Methods. International Journal of Information Technology \& Decision Making, 14 (06), 1171-1187. doi: https:// doi.org/10.1142/s021962201550025x

11. Saati, T. L. (1993). Prinyatie resheniy: Metod analiza ierarhiy. Moscow: Radio i svyaz', 278. Available at: http://pqm-online.com/ assets/files/lib/books/saaty.pdf

12. Maksimenko, O., Pancheva, H., Madzhd, S., Pysanko, Y., Briankin, O., Tykhomyrova, T., Hrebeniuk, T. (2018). Examining the efficiency of electrochemical purification of storm wastewater at machinebuilding enterprises. Eastern-European Journal of Enterprise Technologies, 6 (10 (96)), 21-27. doi: https://doi.org/10.15587/1729-4061.2018.150088

13. Isaienko, V., Madzhd, S., Pysanko, Y., Nikolaiev, K., Bovsunovskyi, E., Cherniak, L. (2019). Development of a procedure for determining the basic parameter of aquatic ecosystems functioning - environmental capacity. Eastern-European Journal of Enterprise Technologies, 1 (10 (97)), 21-28. doi: https://doi.org/10.15587/1729-4061.2019.157089 